\title{
ASPECTS OF MEDIA PRESENTATIONS ON RUSSIANS: YET ANOTHER SPY STORY IN THE MEDIA
}

\author{
Desislava Cheshmedzhieva-Stoycheva ${ }^{1}$
}

\begin{abstract}
The paper presents some aspects of media presentations on a particular ethnic group which in the western psyche brings up associations with Socialism, Cold War Era, wealth, as well as of criminals, and last but not least, as the deadliest secret agents. In particular, the paper dwells on the cases of poisoning of Russian ex-spies in the UK as reflected in the media. The focus is on the way a Bulgarian, a British and a Russian newspaper present the case of the attempted murder of Sergey and Yulia Skripal with Novichok in Salisbury paying attention to the main topics put forward in the media discourse on spies. Some of the coverage of the Bulgarian trace, i.e. Emilian Gebrev, in the case is also analysed.

Using CDA as the main method of analysis, the paper looks into the language used to present the whole case, the voices that get heard on the case, the focus of presentation of each media discourse along with the effect all these have on the general population. The paper argues that although articles on the topic are mostly informative and familiarize the general public with the life of spies with all its enchantment, setbacks, and negative or positive consequences, they also reveal the ongoing struggle for political dominance between today's super powers, the existing ethnic/national and social stereotypes, and finally stir panic, as despite some overt activities the whole activity remains largely clandestine and spies look just like normal people.
\end{abstract}

Key words: spies, media discourse, CDA, Skripal, Novichok

\section{Introduction}

Cases of espionage, or the act of obtaining information in a clandestine manner, have been known ever since there have been populated areas and drive for new conquests. Records of spies are found even in the Bible ${ }^{2}$, Ancient China ${ }^{3}$, Ancient Egypt, etc. (see also Yuen, 2014). It is believed, for example, that if Julius Caesar had read the list of conspirators which was given to him minutes

1. Associate Professor, PhD, Department of English Studies, Shumen University, Bulgaria, e-mail: d.stoycheva@shu.bg, ORCID: 0000-0003-0433-8087.

2. Moses was the first one to send spies to Israel and then Joshua did the same, however, the destination was Jericho (see Dubov, 2017).

3. Sun Tzu is quoted saying: "One who knows the enemy and knows himself will not be endangered in a hundred engagements" (Yuen, 2014, p. 110). 
before he was murdered, he would have survived (Ehoward, 2016). As Ehoward summarises it, "[t]he intelligence business is as old as civilization itself, and once the steps in the process have been identified, they can be traced in almost any civilization that left historical records" (ibid.).

Almost everyone has heard stories of spies who were so skillful in their art that it was difficult to tell them apart from common people. And if there might be people who have not been aware of the extensive use of such individuals during the world wars and the Cold War afterwards, there is probably not a single individual who has not heard or watched a spy movie, the James Bond ones being particularly famous. The pervasiveness of the image of the spy has affected even children's literature and more specifically the Harry Potter series where the teacher of Durmstrang Igor Karkaroff is presented using the features of the "typical" Eastern-European spy - cold blue eyes, treacherous, and possessing dark powers (see Cheshmedzhieva-Stoycheva, 2017).

Regardless of the media, there is a trend that is frequently followed in the presentation of spies, namely, if the agent comes from the West, he/she is usually presented as the good guy who always wins as he/ she usually fights for or defends a noble cause. Eastern spies are generally the bad guys the West should defeat, as they pose a threat to the existence of the latter. The polarity is not accidental and is reflective of the Us - Them presentations where the left part of the dichotomy is associated with everything good and own, while the right part - with everything negative and other, even foreign. Nowadays, however, with the free passage of people and goods, as well as due to politics, the spaces traditionally occupied by own and foreign are transformed and the foreign can frequently be found residing within the confines of the own. The same is pertinent to the topic at hand, as foreign spies who have become double agents seek refuge and protection in countries previously considered their targets, or simply put "enemies". Thus, Russian double agents and spies migrate to the West in search of security and sometimes a new life trying to get out of the Kremlin's reach.

In 2006 the media worldwide broke the news of the Polonium poisoning of $\mathrm{Mr}$. Litvinenko by the former KGB officer Andrei Lugovoi. Two years afterwards, there was another story of the alleged poisoning of a double agent, Gordievsky ${ }^{4}$, who claimed he was poisoned by the Kremlin, and Lugovoi caught the media attention in 2008 and again in 2012 (see Ivanov \& Cheshmedzhieva-Stoycheva, 2012). In 2018 there was yet another spy story in the media, this time associated with Sergei and Yulia Skripal, in which both the father and the daughter had been poisoned with a nerve agent called Novichok in their home in Salisbury, UK.

4. For more information on Gordievsky's story see Macintyre, B. (2019). The spy and the traitor: the greatest espionage story of the Cold War. UK: Viking. 
The short recapitulation of media coverage on spies shows the ongoing activity of Russian intelligencers and the actions undertaken against them by other Russian secret agents. As scare and negative news sell, media pick up on these and publish long stories detailing every single aspect of a case. The additional interest in such spy stories is provoked by the statements issued by the authorities of the countries involved - after all, it is all about politics.

In the context of the above discussion, this paper marks an attempt at critical discourse analysis of media publications on the Skripals looking at the language used and the effect these media presentations have on the public.

The corpus of this study is comprised of a total of 156 publications in the British (The Independent featuring 36 articles), the Bulgarian (Dnevnik - 80 articles) and the Russian (The Moscow Times ${ }^{5}-40$ articles) media published in 2018 and the beginning of 2019 .

\section{Previous Studies}

Although the topic is quite intriguing, there is not much research on the discourse on spies in the media. There are some references to the image of Russian spies and their stereotypical presentations (see Cheshmedzhieva-Stoycheva, 2017; Ivanov \& Cheshmedzhieva-Stoycheva, 2012; Mercouris, 2016) as well as an analysis of the conceptual metaphor US-RUSSIA FOREIGN POLICY IS COMMERCIAL TRANSACTION (Arcimaviciene, 2013, p. 14), along with some analyses on the involvement of US journalists as spies for Russia during WWII and the Cold War (Lovelace, 2015). The latter, however, marks a historical account of the involvement of such American spies, and does not trace the way the issue has been presented in the media.

A very informative account of the story of the Skripals has been presented by the journalist Mark Urban (2018) in his The Skripal files: The life and near death of a Russian spy which he wrote as a result of his interviews on espionage with Sergei Skripal, a former Russian spy for MI6. As stated by Urban himself (2018, p. vii), a pivotal place in the narrative was dedicated to the 2010 spy swap at Vienna airport. The same event was mentioned by Arcimaviciene (2013, p. 15) who quoted some of the headlines from the British media that qualified the event as a

'Cold-war style prisoner exchange' (BBC News, 9 July 2010; CCN News, 10 July 2010) and 'a spy scandal' (The Guardian, 10 July 2010), and noted its significance for its novelty (the first public spy swap in for more than

5. The Moscow Times is an opposition-leaning newspaper issued in English which deals with investigative journalism. 
25 years) and oddity (the 10-for-4 spy exchange) (Arcimaviciene, 2013, p. 15).

Though scarce, the existing research provides a frame that can be applied to the corpus at hand and help draw conclusions on the spy discourse used in the analysed sources.

Looking at the frame theory (Carter, 2013) and acknowledging the conventional nature of cognitive patterns (Fillmore \& Baker, 2009), it can be hypothesized that the spy frames employed by the analysed newspapers will be similar ${ }^{6}$ and will generally include a person sent by his/ her home country to work undercover in another country in order to obtain information that can be of significance for the former. In addition to the undercover agent(s), there are two countries which are also involved, i.e. the issuing one and the target one, which can metonymically also refer to the real heads of state or MPs responsible for the involvement of the spies. The extended spy frame, as in the case of Skripal, can involve different types of spies: double agents, ex-spies, active spies, as well as weapons or types of attacks, and family members. The interesting difference that is sought, however, is in the foregrounding of different parts of the spy frame in the presentation of the event by the three different newspapers as these slight nuances in the delivery of information will show the differences in perceptions which will be triggered by the differences between the three cultures.

\section{Analysis}

The event which has been reiterated in the various media publications on the topic can be summarised as follows: Sergei Skripal, a former Russian spy for the $\mathrm{GRU}^{7}$ has turned double agent in 2004 and has subsequently been revealed as such by Russia and sentenced to 13 years in prison. In 2010 he was pardoned by the then president Medvedev and had been part of the spy swap between the US and Russia at Vienna airport and relocated to the UK where he settled in Salisbury. On March 4, 2018 he and his daughter were poisoned with Novichok, a nerve agent allegedly developed by Russia. Soon after the Skripals were found, the UK blamed Russia for the attack and using information from CCTV footage and intel by Bellingcat, The Insider and Fontanka (independent information

6. Ehoward (2016) gives an account of four stages of modern information gathering: targeting, collection of data, analysis, and dissemination.

7. GRU - abbreviation for (Military) (formerly) the Soviet military intelligence service; the military counterpart of the KGB [from Russian 'Glavnoye Razvedyvatelnoye Upravleniye' - Main Intelligence Directorate]; while KGB stands for The intelligence and internal security agency of the former Soviet Union. [Russian, from K(omitet) G(osudarstvennoî) B(ezopasnosti): komitet, committee + gosudarstvennor̆: genitive of gosudarstvenny $\breve{1}$, of the state + bezopasnosti, genitive of bezopasnost', security.] (Collins, 2014) 
agencies), two GRU agents had been named as responsible for the attack. Subsequently, there had been three more collateral victims, one of whom died. The event gave UK and its allies the reason to send Russian officials out of their countries and Russia reciprocated, thus marking a new stage in the international relations between the country and the West.

Applying the above sketched frame to the corpus of articles from The Independent (I), The Moscow Times (MT) and Dnevnik (D), the agents who can be singled out are the victims Sergei and Yulia Skripal (the latter believed to be a collateral victim, Sergei being deemed the primary target); Russia and the UK - the former as the original spy issuing country, the latter as the target with a swap of their places in 2004 when the primary target turned a double agent selling information on Russia to MI6; three more collateral victims, named as DS Nick Bailey, Dawn Sturgess, and Charles Rowley; initially two suspects, both of whom decorated GRU agents, i.e. Alexander Petrov and Ruslan Boshirov, subsequently a third perpetrator has been named as Ruslan Fedotov; weapon - the nerve agent Novichok. The frame has been additionally extended to involve the agencies that named the culprits: Bellingcat, Insider, and Fontanka as well as some scientists who worked on Novichok and therefore provided further information on its use and possible sale and/ or transportation outside Russian labs.

It is natural that the main agent of a frame, as the pivot of the whole event, will be foregrounded and the information thus made more salient. True to its strategy of highlighting important information right in the title of its articles, The Independent used a well-established structure, i.e. a noun phrase or a personal name denoting the event as the Theme in most of its titles related to the case. Thus, the noun phrase used in initial position becomes a catch phrase of a kind which is easily discernible for the readers.

Sergei Skripal's name occupies the initial position in 7 of the headlines, and in another 2 his personal name appears along with that of his daughter. Yulia Skripal is the subject of 2 headlines which makes a total of 11 (or 30\%) headlines introducing the main subjects as Themes. The interesting point here is that the function of the foregrounded catch phrases differs: e.g. [1] Sergei Skripal: Former spy was in 'regular contact with Russian embassy', ex-Kremlin officer claims /h/ (In/ 07.03.2018; emphasis mine); [2] Sergei Skripal: Police officer poisoned by 'very rare' nerve agent named as Detective Sergeant Nick Bailey /h/ (In/ 07.03.2018). As example [1] clearly shows the connection between the catch phrase and the information that follows is established by the use of units of the same nominative chain, e.g. Sergei Skripal, former spy, and the extended lexico-thematic field of espionage, e.g. spy, ex-Kremlin officer, Russian embassy, therefore, it provides information related to the main subject. Example [2], however, actually shows another aspect of the puzzle related to the 
poisoning of the ex-spy, namely the extension of the spy frame with collateral victims. Unlike example [1], the headline in [2] bears no direct link to Skripal, therefore, the catch phrase serves as an attention grabber, or a hook, to hold public attention and deliver additional information on the case in general.

The event, specified through the place where the poisoning has taken place, is the subject of 9 (or 25\%) headlines, e.g. [3] Salisbury spy poisoning: Yulia Skripal says she is 'lucky to have survived' and would one day like to go home to Russia / $\mathrm{h} /(\mathrm{In} / 23.05 .2018)$, while the poison is the subject of 2 headlines, e.g. [4] Salisbury novichok attack: The most implausible claims made by Russian men accused of attempted assassination of Sergei Skripal /h/ (In/ 13.09.2018). Similar to the two examples above, the catch phrase can be linked either to the subjects and the main agents in the spy poisoning frame or to some additional perpetrators, thus, forming a kind of a thematic field. An interesting switch in the terminology used is the change of poisoning with attack which changes the charge and the associations as the former can be unmediated, however, the second is not and is generally associated with imposed force.

In another group of articles, Russia and its president Putin are explicitly mentioned and given first position in 5 (or 13\%) of the headlines, e.g. [5] Vladimir Putin calls poisoned Russian spy Sergei Skripal 'simply a traitor and a scumbag' $/ \mathrm{h} /(\mathrm{In} / 03.10 .2018)$. The choice of foregrounding the main elements in the spy frame unequivocally shows the focus of the British newspaper primarily on the people and places involved in the event. Combined the titles focused on the main elements of the spy frame come to $68 \%$ or more than half of all analysed content-intense structures. In addition, The Independent uses easily recognizable Themes in order to attract readers' attention and gives the new information related to the whole event as the Rhemes ${ }^{8}$.

Looking at the choice of headlines in The Moscow Times we can notice a difference in the focus of presentation. There are no established patterns of headlines, however, the information that the newspaper chooses to foreground in 14 (or 35\%) of the headlinesis related mostly to Russia, e.g. [6] Kremlin on Skripal Suspect Identification: 'Many People Look Alike' /h/ (MT/ 28.09.2018). Even when Skripal is featured in the headline, he is presented through his relation to Russia "former Russian spy scandal", "Russian ex-spy", etc., or as a modifier "Skripal suspect identification", while his name denoting the person behind it is not explicitly mentioned in the headline in initial position. This peculiarity can be attributed to the Russian roots of the newspaper as well as to the general position of defence and detachment from the whole case that

8. Looking at some of the pragmatic functions of newspaper headlines, Ivanova (2020) makes the observation that the use of a nominal group followed by a colon is mostly used to draw the attention of the audience to the new information added to an already familiar topic - a goal achieved through the distribution of familiar Theme and a new Rheme. 
Russia has undertaken. What is more, Russia is a very powerful country and its president is known for his resolution and firm politics and as shown in one of the headlines above, the attitude exhibited by Putin to Skripal is very indifferent and he even allows himself to insult the former spy calling him a "scumbag" and a "traitor". Thus, although The Moscow Times tries to sound independent and publish various opinions on the matter, the editors seem to unconsciously back their president by refraining to give substance of the "traitor" directly in the headlines describing the event. The focus seems to be more on the ruling elite presented metonymically through the use of the Kremlin in initial position or on the opinion of the head of the country, however, it is difficult to define a particular pattern in the structure of the headlines that have been published.

The Bulgarian Dnevnik does not have a clearly set headline structure either. However, Russia related information on the case is foregrounded in 14 (or 17\%) of the headlines, e.g. [7] Кремъл приема за недопустими обвинения по случая "Скрипал" /h/ ("Kremlin views the accusations on the Skripal case as unacceptable" ${ }^{\prime}-\mathrm{Dn} / 06.09 .2018$ ), while Skripal is the Theme of 9 headlines, e.g. [8] Скрипал може да е отровен с химическо оръжие на НАТО, обяви Лавров /h/ ('Skripal might have been poisoned with NATO's chemical weapon', Lavrov announced - Dn/ 14.04.2018) and the Bulgarian link to the whole case is made salient in 5 of the headlines, e.g. [9] България е солидарна със съюзниците по случая Скрипал, каза зам.-министър пред руския посланик /h/ ('Bulgaria shows solidarity with its allies on the Skripal case, said the deputy minister in front of the Russian ambassador' - Dn/ 30.03.2018).

This initial analysis of the structure of the headlines chosen by the three newspapers reflects in a way the stance of each country in the matter. The UK as the country that has provided shelter for Skripal and as the location of the attempted assassination of the agent is naturally focused on the information on the victims, the place the alleged poisoning took place as well as on the possible identity of the perpetrators. Russia, on the other hand, undertaking the role of the accused, as the assumed culprits had received their orders from Putin, takes it upon itself to defend itself and play the UK counterpart in the blame game.

The stance of Bulgaria is somewhere in-between. The country has also been affected by the alleged clandestine activities of Russia and a Bulgarian businessman, Emilian Gebrev, involved in the production of weapons in a Bulgarian factory called Emko, has also been poisoned with an agent similar to novichok. Additionally, one of the suspects associated with Skripal's attempted murder, i.e. Sergey Fedotov, was named as the perpetrator of the attempted poisoning of Gebrev. However, it seems that Bulgaria cannot distance itself from the long-time influence of Russia and although an ally to the UK in NATO and

9. Translation of Bulgarian examples into English is done by the author. 
the EU, it cannot take a firm stand as can be seen from the choice of information to foreground on the topic.

Looking at the content of the articles on the matter there appear to be two major patterns in the presentation of the case: the first one is closely related to the person affected and developed through The Life of the Spy, and the second, to international politics presented through the subtopics of The Blame Game, Flexing Muscles, and Expansion and Scare.

\section{The Life of the Spy}

The first major thematic group of articles reflects the general activities, services, and agents involved in the work of the spy. People might expect a resemblance with Agent 007, however, in most of the cases they remain disappointed.

In many of the articles in both the British and the Bulgarian media one can read parts of the general outline presented above, i.e. the fact that Sergei Skripal was a Russian spy turned double agent who was sentenced to 13 years in prison and then pardoned by Medvedev and exchanged for other agents at the Vienna Airport. After the exchange he did not change his identity and lived in Salisbury. The details mentioned in some of the articles talk of a humble existence, nothing of the James Bond flashy style, e.g. [10] Mr Skripal appears to have lived a quiet life in a semi-detached home in Salisbury, but a former associate, Valery Morozov, believes he had not completely retired from espionage. (In/ 08.03.2018). The assumption voiced by Morozov is actually reiterated in other articles as well:

[11] Радиото се позовава на източници в чешките служби. По това време Скрипал се срещнал с офицери от местните служби и им предал информация за възможни агенти на руското разузнаване, работещи в страната. ('The radio relies on sources from the Chech services. At that time Skripal met with officers from the local services and gave them intel on possible agents from Russian services working in the country' - Dn/ 10.10.2018); see also [15].

and leads to the conclusion that "Once a spy, always a spy" and that there is no such thing as an ex-spy. This also provides the motive for the attack - the continuous activity of the double agent and the disclosure of information on his homeland. The latter is further supported by the accounts of continuous surveillance including the general bugging technology on the Skripals prior to the poisoning:

[11] Ex-spy Sergei Skripal and daughter were 'under Russian surveillance' months before Salisbury poisoning $/ \mathrm{h} /$ Phone belonging to double agent's 
daughter reportedly searched for malware which could have tracked her movements /sh/ (In/ 05.07.2018).

The feeling created is of constantly being watched, never feeling secure which is applicable not only to those actively involved with the clandestine activity but to their close ones as well. What is more, the Skripal case itself has been a sort of a wake-up call to other defectors: [12] Mr Skripal, a former military intelligence colonel, had been living openly under his real name after being handed over in a 2010 spy swap and the attempted assassination increased fears held by other defectors. (In/ 18.05.2018). Added to the other cases of dead ex-spies, e.g. Litvinenko, Berezovski, etc., this account contributes to the understanding of what happens to people who are viewed as a threat, or at least a nuisance, to Russia. The strong hand that Russia uses in its dealings with "traitors" is felt in the way the Russian president talks about Skripal and the whole case:

[13] Mr Putin said coverage of the Salisbury poisoning had distorted who Mr Skripal really was. "I see that there is this theory that Skripal was almost some kind of human rights activist," he said. "He's just a spy who betrayed his people. A national traitor, that's who he is. He's just scum." Using the derogatory term "shpion" (spy) rather than "razvedchik" used for Russian agents serving the motherland, the president went on to compare Mr Skripal's actions with prostitution. "Jiggery-pokery between special services hasn't just appeared just now. Spying, like prostitution, is one of the most important professions in the world." (In/ 03.10.2018); [14] Mr Morozov also said he was sure that Russian President Vladimir Putin had nothing to do with the alleged poisoning. "Putin can't be behind this. I know how the Kremlin works, I worked there. Who is Skripal? He is nothing for Putin. Putin doesn't think about him", he said. "There is nobody in Kremlin talking about former intelligence officer who is nobody. There is no reason for this. It is more dangerous for them for such things to happen." (In/ 07.03.2018).

As stated above, the vocabulary used by Putin totally corresponds with his selfesteem as the head of one of the world-powers and one of the most powerful men globally. Only a person with such status can allow himself to use negatively charged language for someone who possesses the skills and knowledge to destroy them. The use of the derogative "shpion", along with traitor, however, shows the contempt for someone who has chanced to give intel on his own people and might also show some concern: if the so-called ex-spy and scum is really nothing, why bother explain one's own stand towards that individual? Mark Galeotti - a journalist for The Moscow Times provides more information that contradicts the descriptors used by Putin:

[15] Skripal was not just any spy, though, but a former insider, a GRU officer who allegedly blew the cover of some 300 Russian agents. Although 
Moscow has a particular grudge against former insiders who turn, that is not in itself usually enough to go to the effort and potential risks of "wet work"- a killing, in their slang. (by Mark Galeotti MT/ 06.03.2018).

Furthermore, it is obvious that the comparison with prostitution used by Putin in [13] tries to belittle the significance of the event and even present it as something normal which has been in existence for a long time, while simultaneously leading the public attention away from Russia as a possible perpetrator. The statements made by Morozov in [14] have a similar purpose, distraction and showing indifference to a person, considered a nothing. In addition, it is easy to see that his expose reiterates the very descriptors used by the Russian president, so it is not clear whose opinion he voices. The last sentence of [14] as well as in [15] suggests the possibility that it truly might not be Russia who is responsible for the attack on Sergei Skripal, however, the array of cases of murdered defectors actually hints on the opposite.

Nobody can be sure of the motives behind the statement of president Putin but his words do convey his resentment of Skripal and such emotions can be a trigger for further actions against him. Thus, the fact that he uses similar lexis, i.e. scum, for the collateral victims as well, could not be considered a mere coincidence. In this way, Putin tries to show his indifference to the whole case and at the same time, his contempt for the UK in general. The latter could be attributed to the fact that the attack did achieve something, even if it was to but show the British agents that despite their efforts and all the intel they have gathered on the state, the "razvedchiki" can carry out their tasks and get a hit at their targets.

The fear at what might follow, i.e. a subsequent murder attempt, is also voiced and it sounds even more credible as the person quoted is a former military intelligence officer:

[16] "Mr Skripal will almost certainly be moved location," Philip Ingram said. "He might well be offered a new identity. "These sorts of things are not straight forward, but it is work the intelligence services are used to doing and can set that up." (In/ 18.05.2018).

Such accounts do not only introduce the general public to the established practices in the world of secret agencies, but the mere fact that they are needed, suggests the possibility of an ongoing surveillance, threat and possibly further assassination attempts. The importance of the order and the fact that Skripal was not really a nobody is in a way confirmed by the reports on the identity of the possible assassins and the fact that it was not only one man sent after the ex-spy, but three "decorated" agents, as it turns out eventually.

It is important to note that two information agencies, i.e. The Insider and Bellingcat with the assistance of a Russian one, Fontanka, were those who 
managed to uncover the identity of the operatives involved in the case. The latter information is mostly included in the Bulgarian Dnevnik in relation to the Bulgarian link in the case of Skripal, i.e. the Bulgarian businessman Emilian Gebrev who was poisoned with a chemical substance similar to the one used in the case of Skripal.

The details on the assassins widen the frame of espionage: lacking evidence of the existence of such people, fake identity, lack of personal belongings, such as some property, a car, a mobile phone, a criminal or court record or presence in the social networks, a passport number very close to the numbers of those registered at 76 Horoshevskoe shosse which is the address of the headquarters of GRU (see Dn/ 08.02.2019). It also creates the idea that there truly is something fishy about the people who claim to be only visitors in the UK, and leads the readers to believe that the suspects are agents and that they really had the task to kill their target. Why would they otherwise track him for such a long time and use fake identities to travel around?

[17] Руските агенти “Боширов" и “Петров" следили Скрипал в Чехия през 2014 2. $/ \mathrm{h} /$ Обвинените от Великобритания за покушението срещу бившия разузнавач Сергей Скрипал руски граждани са били в Чехия през 2014 г., за да го наблюдават по време на негово съобщение. [...] Според информацията Чепига и Мишкин пристигнали със същит есамоличности в Прага, но на различни дати: първият - на 11 октомври, а вторият след 16 октомври, като трите дни преди това прекарал в Острава, третия найголям град в Чехия. ('The Russian agents Boshirov and Petrov tracked Skripal in the Czech Republic in 2014 / $\mathrm{h} /$ The Russian citizens accused by the UK for the attack on the ex-spy Sergei Skripal were in the Chech Republic in 2014 so that they could watch him secretly during his report [...] According to the information, Chepiga and Mishkin arrived in Prague using the same identities, but on different dates: the first one on October 11th and the second one after October 16th, having spent the three days before in Ostrava, the third largest city in the Czech Republic.' - Dn/ 10.10.2018); [18] The British government previously said Russia had been spying on the Skripals for at least five years. In a letter to Nato, the national security adviser, Sir Mark Sedwill, said the pair were the subject of "interest" from the Kremlin's security services since 2013. (In/ 05.07.2018); [19] "Ако някой шпионира, защо британските служби не са се оплаквали", каза той пред репортери, цитиран от "Ройтерс". "Те винаги се оплакват, ако нещо се обърка. Не видяхме никакви знаци, никакви насоки от британска страна, че те са недоволни от начина, по който живеят (Сергей и Юлия) Скрипал в Солсбъри", каза още Яковленко. ('If someone has been spying, why haven't the British services complained," Reuters quoted him telling reporters. "They 
always complain if something goes wrong. We did not see any signs, any suggestions from the British side that they were dissatisfied with the way (Sergei and Julia) Skripal lived in Salisbury," Yakovlenko added.' - Dn/ 13.04.2018)

As one can easily see, the period of observation mentioned is between 4 and 5 years. This speaks of the perseverance in the spying job. There is probably no one who can say with certainty why they needed such a long time of preparation before they could carry out their wet job but if Skripal was really nothing for the Russian secret services, then why would they spend so many resources on tracking him abroad. The arguments provided by Yakovlenko on the spying activities are merely pathetic as gathering information on foreign activities in one's country is not something that is openly discussed. Furthermore, the suspicion of the agents set on the task and their alleged innocence is increased through the information on the strategy they would frequently employ in order to avoid being tracked [19] билет за обратен полет, който не се използва, и извършване на отклонение, този път през Сърбия. ('a return flight ticket, which is not used, and a diversion, this time through Serbia' - Dn/ 08.02.2019). The very fact that they talk about a strategy, means that it is an established and repetitive pattern, a practice frequently followed whenever there is a task to be carried out, and not just a whim or a chance occurrence (see also e.g. [23]).

The parallel with the Bulgarian case as well as with the one of Litvinenko and of other defectors does confirm the fact that Russian assassins and the Kremlin manage to carry out the task they set themselves on. So their modus operandi seems to be working better than the British one. Or is it the fact that only such cases get voiced?

Some of the doubts and the weak points in the analysis of the attempted murder of Skripal have been raised by Mary Dejevski, a long-time correspondent for The Independent and The Guardian in Russia, in an article published in The Independent on 7 March 2018 titled [20] Sergei Skripal is not Litvinenko - and this is what that really means $/ \mathrm{h} /(\mathrm{In} / 07.03 .2018)$. She confirms that "Russians in the UK seem disproportionately accident-prone", however, she also states that it is very easy to jump into conclusions when one does not know the truth as is the case with the information provided by intelligence services. In a way the journalist hints on the political games that lie behind all actions and words used by said agencies. The example she gives is with the information on the Litvinenko case and the fact that Russia has not done anything to harm two other high-level defectors who have been speaking openly about their work in their home country for years. As Dejevski concludes "Many of the "whats" and the "whys" remain elusive" (In/ 07.03.2018). At the same time, taking the account of the three cases of poisoned or attacked spies mentioned here along 
with the array of other cases of poisoned dissidents publicly known, the odds are against the defectors who have turned sides.

Based on everything said so far, it can be concluded that no one else but the people directly involved, know what has really happened and what is the actual state of affairs. Everything else is speculations based on the information provided in the media. Common people, however, base their opinion on what they hear and read, as generally they do not have a direct contact with people from the secret services. That is why common people are usually subjected to the ideology upheld by the particular media presenting the case, which in publications on internationally significant events is usually reflective of the political stand of the country the media originates from.

The media very frequently employ metaphors in order to present in a more vivid way the problems they deal with. And, as Arcimaviciene (2013, p. 15) quoting Lakoff and Chilton (1989) states, "it is right to claim that metaphors, as one of the primary means of conceptualising the world and reflecting ideologies, shape and justify political behaviour and decisions". In the matter at hand, the media in all three countries have extensively resorted to the use of metonymic representation of the countries standing for the top officials who fight with each other for superiority and try to show their dominance. Thus, countries are personified and presented as competitors in a kind of a contest. The employment of said metaphor is not strange as competition has always existed and has been the preferred way of showing one's power - an observation which has also been supported by Arcimaviciene (2013, p. 15), who states that "[t]he most widely-spread metaphors in the language of politics are of human nature and competitive character."

In the field of international politics, it is all about power, prestige and reputation. Therefore, it is not surprising that one of the major topics analyzed is on the question of guilt and who is to blame.

\section{The Blame Game}

As stated above, through the metonymic employment of the name of the whole country to stand for the decision makers, the whole debate around the Skripal case is presented as a blame game between the UK and Russia - two of the most powerful countries in the world and also two of the countries that are still mindful of having been world empires, though with past glory. As such, they would not shy away from standing their ground, defending themselves, or accusing the one they see as a culprit. Words in political discourse are the weapons that speak of power.

Corresponding with the centre-periphery presentations, Russia is portrayed as an oligarch who is merciless and who never forgets or forgives infidelity. 
Stereotypically the people from the East are fierce and endowed with all negative qualities - they are cruel, uncivilized or primitive, treacherous, vindictive and blood thirsty (see Cheshmedzhieva-Stoycheva, 2017; Kostova, 1997). This description is very well presented through the comparison of Russians with cornered rats. Regardless of the time passed, the grudge is there and it can be taken as the motive for the poisoning:

[21] "These guys have a grudge, and like the rat in a corner, being poked with a stick, they will fight back." (In/ 14.02.2019); [22] We have a motive: Russia would always want to punish a traitor, wouldn't it? [...] the Skripals need protection from a state that tried to kill them; the UK has a duty to ensure their safety. (In/ 04.03.2019); [23] Russian spy: Poisoned Sergei Skripal's wife and son were murdered, alleges Conservative MP $/ \mathrm{h} /$ Putin determined to ensure 'those who betray him know there is a cost to betrayal', warns chairman of the Foreign Affairs Select Committee /sh/ [...] Mr Tugendhat pointed to "threats" made by Vladimir Putin against Colonel Skripal and said the method of the attack was "remarkably similar" to the killing of Alexander Litvinenko. "We are beginning to see, not only a very strong pattern, but a very strong centre to that patternand that centre appears very strongly to be the Kremlin," he said, in a podcast for The Spectator magazine. (In/ 08.03.2018).

As the examples clearly show, the British MP puts on Russia's bill the deaths of the other family members of the double agent, and following the dichotomy goodevil, protector-attacker, presents the UK as the only haven and protector of the ex-spy. The UK is the place where Sergei Skripal has been able to lead a peaceful existence. The comparison of Russians with rats in [21] shows the contempt the British hold against them and the associations with "vicious, unclean, parasitic animals" (Wikipedia/EN) further highlight the negative qualities attributed to Russians, while at the same time hinting on their resolution.

An interesting observation that can be made on the language of the Russian officials, as observed in e.g. [23] above, is the fact that Skripal is not referred to with his military rank in any of the statements made by Putin. This is not surprising given the grudge they hold against him (as presented in e.g. [15] and [21]). British officials, however, do use colonel when they refer to Skripal which on the one hand, shows their esteem for the person, while on the other, can be taken as a strategy employed to irk Russia as the use of colonel strongly contrasts with scum or nobody used by Putin and the other interviewed Russian informants. In addition, the parallel drawn with Litvinenko both confirms the idea that those who betray Russia do not walk out of it unharmed, thereby confirming the stereotype of merciless attitude to defectors, and present this 
as a trend in Russia's politics and a reason to lay the blame for the attack on that country. The two conclusions reached as a result of the analysis on the above noted excerpts from The Independent have interestingly been confirmed by some articles published in the Russian The Moscow Times:

[24] The Skripal Case: Another Example of Russia's Poisoned Politics $(\mathrm{Op}-\mathrm{ed})^{10} / \mathrm{h} /$ Russia's long history of liquidating defectors and enemies of the state is ruining its reputation /sh/ Russia has inherited from the Soviet Union a reputation for being a state with intelligence agencies that repeatedly silence defectors and enemies of the authorities while denying involvement in their murders. (by Pavel Aptekar, Ivan Prosvetov, and Maria Zheleznova was originally published in the Vedomosti business daily MT/ 15.03.2018); see also [68], [69].

In this particular article the headline itself employs a modifier which associates the modus operandi with the weapon used against the former spy. The phrase used can be interpreted in two different ways: first, as politics which is corrupted or generally harmful, and second, as filled with poison or resorting to the use of poison. The ambiguity is skillfully upheld in the subheading, as "liquidating defectors" refers to the second interpretation presented above, while "ruining its reputation" to the first. The excerpt also summarizes the usual behaviour exhibited by the Russian state whenever the murder of a defector is voiced. Bearing in mind that Putin is an ex-intelligencer and being aware of the firm single-handed approach he applies in governing the country of which he is the head, probably it should be no surprise that the language used to describe his politics is from the field of secret services.

The usual modus operandi in case of a spy job being brought in the open is discussed in several other articles as well. For example, Henry Collins in an interview for the Konrad Adenauer Organization in Sofia, Bulgaria, states that:

[25] Когато бъде извършено нарушение на международните норми, виновникът обикновено използва 4-те O-та (отхвърляне, объркване (на информачиите), опорочаване (на вниманието на обществото) и обезсърчаване), за да се покаже като невинен и да всее съмнение с активна кампания, каза той, давайки пример с нападението в Солсбъри. ('Whenever there is a breach in international norms, the culprit usually resorts to the $4 \mathrm{Ds}$ - dismiss, distort (information), distract (public attention) and dismay to show up as innocent and instill doubts with an

10.Op-ed ('opposite editorial') - Of or being a newspaper page, usually opposite the editorial page, that features signed articles expressing personal viewpoints. (see American Heritage Dictionary) 
active campaign' he said giving Salisbury attack as an example' - Dn/ 23.05.2018).

The example actually continues the blame game by providing a frame of the actions undertaken by the party considered the culprit. As Collins is an aide to the British Prime Minister against the Russian propaganda in the case, it is not surprising that the Ds described above fit nicely into the actions undertaken by Russia. At the same time, there are some other codes of behaviour that are presented as applicable to the strategy employed by the British state:

[26] Using a formula of "capability, intent and motive" the UK has said it is "highly likely" that Russia was responsible for the Salisbury attack. Questions persist over each part of that formula. An investigation by Russian independent media has already shown that novichok stocks were sold to organised criminals in the 1990s - indicating groups other than the state theoretically have the capacity to kill using such a nerve agent. A widely mistranslated phrase, allegedly uttered by the Russian president - "traitors will kick the bucket" - is regularly used to justify the second strand of the allegation, intent. Mr Putin actually said "traitors will kick the bucket without our help". The Kremlin has formally denied having an assassination list. The third leg of the troika, motive, has puzzled many experts from the start. Mr Skripal was not, apparently, actively collaborating with British security services, and had been pardoned during the spy swap. (In/ 04.04.2018).

The blame this time comes from the British mainstream media trying to sound objective and find the truth about the case. The analysis of the presented formula focuses on the uncertainties showing how phrases and information taken out of context can lead public attention in a particular direction. The pro-Russian stance is also felt through the culturally specific lexis used in reference to the three elements in the mentioned formula, i.e. troika as well as through the use of allegedly showing the uncertainty of the whole blame giving. There is, however, a part of the whole equation that stands in contrast with the opinion voiced in e.g. [1] above, where it was stated that the agent was a "very rare one", or with the statement made by a Russian scientist that: [27] Само Русия може да произведе “Новичок”, според един от създателите на оръжието /h/ (Russia is the only one capable of producing Novichok, according to one of the creators of the weapon' - Dn/ 18.03.2018).

The claim made here is that the substance has been sold illegally to Western European countries (the Czech Republic, Germany), so it is very likely that British intelligencers have carried out the job. The latter has been re-confirmed in other articles as well: 
[28] "Experts tell us that it may well be beneficial to the British special services, who are known for their ability to act with licence to kill," he said (In/ 11.04.2018); [29] Russia's Foreign Ministry Suggests Britain Might Be Behind Yulia Skripal's Poisoning /h/ (MT/ 21.03.2018); [30] U.S. and U.K. Developed 'Novichok' Nerve Agent Linked to Ex-Spy's Poisoning, Russian Official Claims /h/ (MT/ 16.03.2018).

In addition to continuing the blame game, the examples here give some information on the image British spies have with their Russian counterparts. Similar to the way Russian agents are being described, the British ones are also endowed with deadliness as the example suggests that they bring their tasks to a lethal end. The spread of the possible owners of the poison gives the reason for Russia's officials in their turn to blame Yulia Skripal's poisoning on the British and even attribute the development of the poison to the USA and the UK, regardless of the fact that Russian scientists have publicly claimed to have created it, as was stated in e.g. [27] and [67]. The fact that remains unclear is why would the UK want to dispose of an ex-spy who has actually collaborated with them.

Several of the articles published in The Moscow Times foreground the response Russian officials gave to the accusations made by the UK:

[31] Britain's Accusations Against Putin in Nerve Attack Are 'Shocking', Kremlin Says /h/ (MT/ 16.03.2018); [32] Boris Johnson's Comparison of Russia's World Cup with Nazi Olympics Unacceptable, Kremlin Says $/ \mathrm{h} /[. .$.$] Johnson told lawmakers on Wednesday that President Vladimir$ Putin would try to bolster Russia's image through hosting the World Cup in much the same way as Adolf Hitler used the 1936 Olympics in Nazi Germany (MT/ 22.03.2018).

The feelings expressed by Russian officials are actually milder compared to the definitions provided by the British on the act perpetrated by the Russians (cf. e.g. [44] - [47] below). At the same time, the parallels drawn to the Nazi Olympics of 1936 and an arsonist investigating own fire (in e.g. [33]) are telling of the opinion British officials have of Putin. As is well known Hitler used the Olympic games in 1936 to present Germany as tolerant and peaceful and thus try to promote his ideology (see United States Holocaust Memorial Museum). The comparison with Putin brings associations with his firm rule and presents the image of an oligarch, also viewed by many as a dictator, who would not tolerate traitors even though he states otherwise. The articles also make a reference to the Soviet-era (e.g. [35]) when novichok was developed, and the reason for that is mainly to confirm the statement that once an assassin, always an assassin, or, in Putin's case, once an agent, always an agent, thereby the means employed remain the same. The latter has been voiced once again in the comparison used by a UK ambassador: [33] UK ambassador to UN: Russia's 
request to play part in Salisbury nerve agent probe like arsonist 'investigating own fire' (In/ 17.04.2018).

The blame game continues and as a powerful country would never acknowledge its defeat as long as there are some uncertainties and the presumption of innocence, Russia in its own turn tries to transfer the blame to the UK. As stated above, the accusations are voiced in milder terms than the language used by the British, and are presented mostly as claims, implications, and talks attempting to show that the origin of the nerve agent is not Russian:

[34] Salisbury attack: Russia claims Skripals were poisoned using toxin possessed by UK and US /h/ Foreign minister Sergei Lavrov says Swiss lab found substance that was not novichok nerve agent /sh/ (In/ 14.04.2018); [35] Four independent laboratories have concluded the chemical used in the attack was a novichok-class nerve agent, which were originally developed by the Soviet Union, the Organisation for the Prohibition of Chemical Weapons said last week. Their conclusions match that of UK scientists at the Porton Down defence laboratory, which the government said proved Moscow was culpable for the attack after allegedly spying on the Skripals for at least five years. The Foreign Office said there was "no alternative explanation about who was responsible - only Russia has the means, motive and record", and demanded the Kremlin "give answers". Russia continues to deny any involvement in the attack. (In/ 17.04.2018).

The two examples above are also telling of the way each country wants to show its dominance. Russia relies on the expertise of a European lab (although the fact that the Swiss scientists denied said statements, makes one wonder about the legitimacy of the claims made), known for its precision, while the British counter attack with the findings of four independent laboratories which show Russia as the culprit for the attack.

When the version of the American/ British origin of Novichok has been proven unsubstantiated, the Russian authorities fight back accusing the UK of breach of European laws, inhumane attitude to pets and an attempt to hide and/ or destroy important evidence.

[36] U.K. Is Breaking International Law by Withholding Data on Skripal's Daughter, Russia Says /h/ (MT/ 29.03.2018); [37] Russia implies UK destroyed poisoned spy Sergei Skripal's cat and guinea pigs to 'remove important witnesses' / $h /$ 'Is that what the UK usually does with pets? Is that normal practice?' /sh/ (In/ 06.04.2018).

The question used as a subheading in [37] in its turn suggests that this is an established practice in the way British deal with events that might have negative consequences for them. The goal of these statements is to create doubt about the actions undertaken and claims made by the UK. In a further stage of the blame 
game the supporters of Russia use the trump card "intolerance towards Russia" and accuse the UK of staging of the whole attack and instilling anti-Russian sentiments:

[38] The Kremlin has repeatedly denied any involvement in the poisoning, accusing British intelligence agencies of staging the attack to stoke antiRussian hysteria. But those denials have sometimes pushed the realms credibility in the face of an increasing body of evidence produced by internet researchers like Bellingcat, and its founder Eliot Higgins. (In/ 14.02.2019); [39] Britain Poisoned Double Agent Skripal to 'Nourish Russophobia' - Russian State Media /h/ [...] A Russian television host made headlines for breaking the fourth wall last week, warning "traitors" against settling on British soil due to the number of "strange incidents with grave outcomes." Top Kremlin propagandist Dmitry Kiselyov seized on the warning in his weekly talk show on Sunday, calling London a "death trap for Russians." "If you think hard about it, only Britain stands to benefit from the poisoning of the GRU colonel. Simply to nourish its Russophobia," Kiselyov said during a segment on his flagship Vesti Nedeli news show on Channel One. [...] Another TV host on Channel One, Valery Fadeev, said that the poisoning "looks like a provocation, a covert operation against Russia." "They use agents who are no longer needed, [who are] useless," the host said in a Voskresnoye Vremya segment. (MT/ 12.03.2018); see also [50].

The Moscow Times gives an account of the coverage of the case in the mainstream media and the ideology some of the TV hosts are trying to sell to their viewers. As the examples show, the UK is presented as a place that is far from welcoming for Russian expats. The lexical use which is interesting to note here is that the people in question are referred to first with the generic Russians and then as traitors which would be insulting to the common people. One cannot but wonder why, if the hosts and the Russian officials consider these people traitors, would they care about their safety?

There are, however, supporters of Russian politics and behaviour even among the journalists in the UK. The account of the story in the article written by Mary Dejevski does hint on the existence of some gaps in the case which provide food for some thought, especially given the fact that Russia needs its reputation prior to the World Cup:

[40] Why would Russia risk its reputation so close to the World Cup, when it hoped to show a friendlier face to the world? Why would Vladimir Putin jeopardise future spy exchanges by signing off on the assassination of a swapped spy? Why would Russia take eight years to take its vengeance, and choose the very time when Skripal's daughter was visiting? Other 
than as a "rogue" operation, none of this made much sense a year ago, and those same doubts remain now. (In/ 04.03.2019).

Although the article does point to some of the weak points in the case, the attempt at attributing the attack to rogue agents is suspicious, especially given the fact that initially any possible Russian involvement was denied. In addition, the good reputation reason in a way harks back to the comparison with Nazi Olympics made by Johnson above. Why would someone be issued a business visa if they are not going on a business trip? And how would such a visa be issued without the necessary supporting documents, if not through the explicit order given by a high official?

[41] Salisbury novichok attack: The most implausible claims made by Russian men accused of attempted assassination of Sergei Skripal /h/ Russians say their visit to Britain 'wasn't a business trip' but they arrived on business visas / $\mathrm{sh} /(\mathrm{In} / 13.09 .2018)$

So, in a way, the wolf changes its coat, but not its disposition. And as far as the timing is concerned it may well be argued that it was only at that time that the agents had a direct access to their victim and had decided on the particular way to carry out their mission. Nobody can be sure about the reasons behind the choice of time but the discoveries made by information agencies in Russia itself cannot be refuted and actually make all the claims of non-involvement of Russia unsubstantial:

[42] Leaked passport files with old passport photos appear to show a young version of the same man British authorities have tied to the Skripal poisoning. "This finding starkly contradicts both this man's statements, as made in a TV interview to Russia's state-run RT network, and President Vladimir Putin's assertions that the person in question is merely a civilian named Ruslan Boshirov," Bellingcat said in its report. (MT/ 26.08.2018)

The facts stemming as a result of fieldwork conducted in the villages of the agents charged with the order to dispose of Skripal are indisputable and even the Kremlin has decided to remain silent claiming they would not get involved in "media discussions" (see MT/ 23.10.2018), which again marks an attempt on behalf of Russian authorities to belittle the importance of the whole case. The conclusion reached is that the spy scandals show that although the work of the spies might be mocked abroad and perceived as bumblers or sad sacks, the Russian army's influence is growing and it is still actively carrying out its "black operations":

[43] Espionage Scandals Show Russian Army's Growing Clout $/ \mathrm{h} /$ Russia's military spies are being mocked abroad as bunglers but the army's influence over Kremlin foreign policy is growing and there is little likelihood it will halt its "black operations". [...] Intelligence experts 
say the GRU has stepped up its activities including black operationscovert missions that are not attributable to the organisation carrying it out - as tensions mount between Russia and the West, which has imposed sanctions on Moscow over the annexation of Crimea. "What Russia is doing is operating by wartime rules which means particularly that the GRU has been let off the leash," said Mark Galeotti, a fellow at the European University Institute in Florence. [...] Putin, a former intelligence officer himself, sounds defiant. He said last week espionage was one of the world's most important professions and dismissed Skripal as a traitor. [...] "The army's influence will rise," said R. Politik's Stanovaya. "Putin believes Russia is in a state of war." (MT/ 09.10.2018).

The last statement can provide the reason for the attack on Skripal as "everything's fair in war". If Putin believes that they are in a state of war, then any means is justified, even the use of illegal chemical weapon.

The accounts provided by the UK of the activities of Russia emphasize and support the stereotype of the state conducting merciless and cruel politics against anyone who has dared to oppose them:

[44] A government spokesman said the Skripals would still need ongoing care, adding: "The fact that all three victims of this incident have been discharged from hospital does not alter the fact this was a brazen and reckless attack - attempted murder - using an illegal chemical weapon." (In/ 18.05.2018); [45] "I would add that the complex investigation into the attempted murders of Yulia and Sergei remains ongoing and detectives continue to sift through and assess all the available evidence and are following every possible lead to identify those responsible, for what remains a reckless and barbaric criminal act. (In/ 05.07.2018); [46] Sergei Skripal: Police officer poisoned by 'very rare' nerve agent named as Detective Sergeant Nick Bailey/h/ Home Secretary attacks 'brazen and reckless act...attempted murder in the most cruel and public way'/sh/ (In/ 08.03.2018); [47] Preliminary enquiries have focused on the former military intelligence colonel as being intended target with his daughter seen as a collateral victim. But the severity of the attack with the use of such a lethal ingredient showed a "quite staggering ruthlessness," a Whitehall official said. ( $\mathrm{In} /$ 08.03.2018).

As the examples clearly show the most frequent descriptors used are brazen, reckless, cruel and ruthless - all negatively charged and confirming the stereotypical image of Russia in the West. As many of the analysts have pointed out, all this contributes also to the negative attitude towards Russia, and has resulted in political withdrawal of Western diplomats:

[48] The attack on the Skripals prompted the biggest Western expulsion of Russian diplomats since the Cold War, as British allies in Europe and 
the United States sided with the view of the prime minister, Theresa May, that Moscow was either responsible or had lost control of the nerve agent. (In/ 05.07.2018); [49] Whether we can prove Moscow's involvement in the Skripal case or not is irrelevant $/ \mathrm{h} /$ The poisoning is severing Russia's relationship with the West/sh/ (In/ 04.04.2018); [50] The Skripal poisoning has deepened Russia's international isolation. Britain accused it of using a military-grade chemical weapon on its soil and Washington, rallying to London's support, has warned it will impose new sanctions on Russia. Moscow has denied any involvement in the Skripal poisoning, saying Western states are gripped by "Russophobia" and that British authorities have failed to produce any evidence. (MT/ 28.09.2018)

The act hints on the importance the Western world attributes to the whole case and the resolution they have at jointly stating their opinion, i.e. that such infringements on the activities and lives of UK citizens are not tolerable.

The position taken by Bulgaria is one of servitude. Bulgarian officials do not want to offend either of the two powers involved in the conflict, and even the fact that a Bulgarian businessman has been attacked in a manner similar to Skripal does not provoke any firm reaction. And while some politicians, such as Kostov define Russia's action as a "hybrid threat" (Dn/ 25.03.2019), others claim that Bulgaria's response is reasonable and working: [51] Според Илияна Йотова българската позиция по случая "Скрипал" е "разумна и работеща" $/ \mathrm{h} /$ ('According to Iliyana Yotova Bulgaria's position on the Skripal case is "sensible and working" - Dn/ 31.03.2018). And still others claim that it is a proof that Russia's influence in the country is still very strong [52] Стефан Тафров: България затвърди убеждението, че руското влияние е много силно /h/ ('Stefan Tafov: Bulgaria has strengthened the belief that the Russian influence over it is very strong' - Dn/ 02.04.2018).

\section{Flexing Muscles}

Rather than just blaming each other for the poisoning of the Skripals the two countries involved try to show their might expressed through the FLEXING MUSCLES metaphor.

In several of the articles, in all three of the analysed newspapers, it has been hinted and in some places even directly stated that if the perpetrators really were sent by Russia, the outcome would not have been positive:

[53] Speaking at a press conference alongside Angela Merkel in Sochi, Vladimir Putin wished Mr Skripal "good health" but suggested he would have "died on the spot" if novichok had been used. (In/ 18.05.2018); [54] Soviet Scientist Behind Nerve Agent Rules Out Russian Hand in Spy Scandal /h/ [...] "It's hard to believe that the Russians were involved, given 
that all of those caught up in the incident are still alive," he said. "Such outrageous incompetence by the alleged (Russian) spies would have simply been laughable and unacceptable." (MT/ 20.03.2018); [55] All Would Have Died If Russia Was Behind Salisbury Attack, U.K. Novichok Victim Told/h/ (MT/ 07.04.2019);[56] “Толкова нескопосано изпълнение на операция не е характерно за руското военно разузнаване" "Това е една зле планирана, нискобюджетна и непрофесионално изпълнена операция, което не е характерно за руското военно разузнаване. Много от фактите говорят за солова акция. При “Скрипал” можем да намерим мотив, че руската държава е планирала и провела това, но при Гебрев - няма такъв мотив. Толкова нескопосано изпълнена операчия, няма как да е дело на такова сериозно разузнаване. Ако беше проведена такава операция, тези хора нямаше да бъдат с руски паспорти, нямаше да пристигнат с полет от Москва, нямаше да отседнат в един хотел, нямаше да обикалят, дори нямаше да се срещат преди самата операция”, коментира Йовчев. ('Such a careless execution of an operation is not typical of Russian military intelligence". "This is a poorly planned, low-budget and unprofessionally executed operation, which is not typical of Russian military intelligence. Many of the facts speak of a solo op. In Skripal we can find a motive for the Russian state to plan and carry out an attack, but in Gebrevthere is no such motive. Such a sloppily executed operation cannot be the work of such serious intelligence. If such an operation had been carried out, these people would not have had Russian passports, would not have arrived on a flight from Moscow, would not have stayed in a hotel, would not have toured, would not even have met before the operation itself," Yovchev commented' - Dn/ 11.02.2019)

All examples explicitly state that the Russian special services do not make mistakes and never miss their targets. Putin himself is quoted boasting in a way with the deadliness of Novichok, thereby the skill of his agents in its application. The reputation of Russian spies is actually voiced not only by the interviewed Russian scientists or analysts but also by Bulgarian officials as well as by the victims of the nerve agent. The deadliness of Russian agents is further highlighted by the fact that the failure to do away with Skripal for good is described as incompetence $e^{11}$ - something which is not characteristic of secret services. It is even more disconcerting to read that the incompetence

11.The same lexeme though hyped up is used by Prof. Leonid Rink, one of the scientists who have worked on the development of Novichok, whose words have been quoted by the Bulgarian Dnevnik: [57] "Подобна скандална некомпетентност от предполагаеми руски агенти просто е смехотворна и неприемлива", цитира думите му РИА "Новости". ("'Such scandalous incompetence of alleged Russian agents is simply ridiculous and unacceptable,” RIA Novosti quoted him as saying.' - Dn/ 20.03.2018) 
can be considered laughable and unacceptable. This coincides with the image Russians have of themselves as tough guys able to withstand everything, a stereotype which stands in contrast with the perception they have of the British secret services as described in [19] above, i.e. sissies who wine and complain every time something is not the way it should be.

At the same time, it is interesting to note that the lexis used in reference to the attack on the Bulgarian businessman Gebrev is similar to the one employed in the description of Russian spies, i.e. an op carried out sloppily as well as operation which was ill-planned, low cost, and unprofessionally carried out. The striking fact is that a similar approach as the one described in the case of Skripal is traced out, however, in the Bulgarian example the official claims that all this is uncharacteristic of Russian intel. Despite the observed difference in the attitude to the two cases, which is probably due to their significance (Skripal being considered of a higher profile than Gebrev) as well as selfesteem (Bulgarian officials show lower self-pride ${ }^{12}$ ), both examples stress on the infallibility in terms of planning and execution of a task by Russian secret agents.

Furthermore, some of the articles of the analysed newspapers feature direct threats foregrounded in their headlines: [59] Русия няма да признае разследването за "Новичок" и предупреди Лондон: Ще съжалявате /h/ ('Russia will not recognize the Novichok investigation and warned London: You will be sorry' $\mathrm{Dn} /$ 05.04.2018). In the last example the whole attitude of the UK and the West in general is described as "a propaganda war" and "theatre of the absurd" which bring different associations but hint on the inconsistency of British accusations. At the same time, "you will be sorry" sounds serious enough. The method of paying back is elaborated in another article published in Dnevnik:

[60] Кремъл ще продължи боя без правила сьс Запада /h/ [...] В очите на руската върхушка всяко отстъпление е поражение. Сигурен съм, че Москва обмисля вече т.нар. асиметричен отговор за Запада. Има си за тази цел и хакери, и пропагандни ресурси, а и въоръжени сили. Не става дума за студена война. В онази имаше все пак някакви правила. В новата война на Русия със Запада такива няма да има. ('The Kremlin will continue the free fight against the West / h / [...] In the

12. This aspect has been suggested in an analysis published in the Bulgarian Dnevnik, titled [58] Защо Москва не коментира (и няма да коментира) по сьщество случая “Гебрев" /h/ [...] Няма и да го коментира по няколко причини, основната от които е, че българският случай е твърде, твърде “ниска топка” за Кремъл, за да му се придава тежест с официална реакция. ('Why Moscow actually fails to comment (and will not comment) the Gebrev case /h/ [...] It will not comment on it for several reasons, the main one of which is that the Bulgarian case is too, too "low ball" for the Kremlin to give it any substance with an official reaction.' - Dn/ 26.02.2019) 
eyes of the Russian elite, any retreat is a defeat. I am sure that Moscow is already considering the so-called an asymmetric response to the West. There are hackers, propaganda resources, and armed forces for this purpose. This is not about the Cold War. There were at least some rules in that one. In Russia's new war against the West there will be none.' $\mathrm{Dn} / 2$ 29.03.2018)

In addition to the generally belligerent character attributed to Russian people, this time suggested through the use of a free fight, the example also provides a glimpse at the thinking or psychology of the elite and the new means of war that they will employ against the West.

The UK in turn also does not hold back and uses threats against Russia. They are, however, of a different kind and rather than focusing on negative qualities as deadliness, present the UK as the noble knight in a shining armour who is going to save the rest of the world from the threat posed by the evil dictatorship of Putin:

[61] Britain is 'in the lead' in trying to counter Vladimir Putin's threat, Boris Johnson insisted /oh/Boris Johnson threatens fresh Russia sanctions if Kremlin is responsible for Sergei Skripal 'poisoning' /h/ Foreign Secretary also suggests 'UK representation' at this summer's World Cup in Russia cannot 'go ahead in the normal way' /sh/ ( $\mathrm{In} / 06.03 .2018)$ [62] Boris Johnson threatened fresh sanctions against Russia if it is proven to have poisoned a Russian double agent in Wiltshire, as he branded the country "a malign and disruptive force". (In/ 06.03.2018); [63] I know that Nato will remain seized of the need to confront the increasingly aggressive pattern of Russia behaviour of which the attack in Salisbury was an acute and recent example (In/ 13.04.2018).

Boris Johnson even allows himself to tarnish Russia, metonymically describing the whole country as malign and disruptive, as well as aggressive, qualities transferred from the image Putin has for the international audience. The measures taken against the country are also presented as more refined, though efficient on a bigger scale, i.e. sanctions that would affect not only the real perpetrators of the attack but the whole country, its image and its economy as well.

All three aspects of the case show the stand of the countries involved in the case as well as the perception they have of each other. At the same time, these aspects as they are highly aggressive are conducive to the feelings of scare and escalation of tensions caused by the case. 


\section{Expansion and Scare}

Subsequently to the attack on the Skripals it became known that there have been collateral victims as well - people who just happened to touch a perfume bottle smeared with the substance (Dawn Sturgess and Charles Rowley) or people performing their duties, such as the police officer who was on the spot (Nick Bailey). The fact that the substance is invisible and has been transported in a way that would not provoke any suspicion raises questions on how many more people might have been affected had the phial of perfume been left in the open and not in the trash. This only supports further the claims made by Russian scientists, as well as by Putin, that the Novichok is very lethal and the dead could be a lot more, which naturally brings additional scare to the readers (see [53] - [55]). The same effect is obtained when all the places where spies are operative or have been spotted are mentioned. The reader is left with the impression of networks of spies operating globally:

[64] British officials have blamed agents using the names Alexander Petrov and Ruslan Boshirov for the Salisbury attack /oh/ Salisbury novichok attack: Bulgaria to investigate third suspect in Skripal nerve agent poisoning $/ \mathrm{h} / 45$-year-old Russian agent linked to British and Bulgarian poisonings /sh/ (In/ 10.02.2019).

Looking into the possible mistakes made by the spies when they failed to kill their targets, people voiced the possible loss of control over the Secret services by Putin and the possibility of them taking up separate orders:

[65] Покушението срещу бизнесмена Емилиян Гебрев не е пряко свързано с опита за ликвидиране на бившия агент Сергей Скрипал, а евентуална руска връзка в българския случай по-скоро би означавала, че Москва няма контрол над собствените си спеислужби и техните служители в момента се занимават и с частни поръчки. ('The assassination attempt against the businessman Emilian Gebrev is not directly related to the attempt to liquidate former agent Sergei Skripal, and a possible Russian connection in the Bulgarian case would rather mean that Moscow has no control over its own secret services and their employees are currently dealing with private orders.' - Dn/ 11.02.2019); [66] “Ако се потвърди информацията за частна поръчка, която е извършило руското разузнаване - това е доста опасно. Това означава, че Владимир Путин няма контрол върху системите за сигурност. Има няколко фактора в подкрепа на тази теза - след случая “Скрипал”, той уволни 15 генерала”, каза Йовчев и допълни, че това не е първата чистка на руския президент в армията. (“"If the information about a private order carried out by the Russian intelligence is confirmed, it is quite dangerous. This means that Vladimir Putin has no control over security systems. "There are several factors in support of 
this thesis - after the Skripal case, he fired 15 generals," Yovchev said, adding that this was not the first purge of the Russian president in the army.' - Dn/ 11.02.2019); see also [43].

In addition to the increasing number of secret agents popping up in various parts of the world as a result of the investigation led by information agencies, the accounts of deadly substances being sold to unknown entities to serve unknown purposes also provokes fear:

[67] What the affair does show, however, was that in the crippling poverty of the Russian 1990s, dangerous military-grade poisons did occasionally go walkabout. And it is not likely that Professor Rink was the only scientist unable to resist criminal forces. [...] With the substance floating about on the black market, any number of criminal and near-state groups could potentially have that capacity. [...] "These suspensions are so dangerous that even the smallest mistake will result in tragedy," says $\mathrm{Mr}$ Mirzayanov. "You're bound to have a mistake if you have no experience. And it's here that we're clearly talking about a state or military level of expertise." (In/ 13.04.2018).

Mentioning dangerous military-grade poisons, criminals, and tragedy in one and the same example is enough to stir some panic. The same goes for the frequent resort to the idea of a war going on between Russia and the rest of the world. As seen above Russia is accused of entering a state of war that is very different from the Cold War and is in different examples described as: vicious shadow war, free fight, or the adoption of new rules of espionage which are dangerous not only to selected high-profile targets but to the general public as well:

[68] Former Russian Spy Scandal Suggests the Old Espionage Rules Are Breaking Down (Op-ed) /h/ With Skripal's hospitalization, a vicious shadow war may be looming /sh/ It is hardly surprising, though, that this is the suspicion. It's also not surprising that Moscow's hand is being seen in the incident, given not only the murder of defector Alexander Litvinenko in London in 2006, but a string of mysterious deaths in recent years. It seems to reflect a breakdown in the old etiquette of espionage, not only foreshadowing an even more vicious "shadow war" to come, but also challenging Western states to come up with new ways to respond to and deter these kinds of outrages. [...] Increasingly, though, the Federal Security Service (FSB), the main domestic security agency, is also active abroad. This is a very different service, one of political policemen used to operating without rules, with impunity, and under the benevolent protection of the Kremlin. They neither know nor care about the old etiquette. Their service is powerful enough not to care if its adventures cause problems for the foreign ministry and, indeed, unlike the GRU 
and SVR, many FSB networks do not even operate outside embassies. They are often amateurish, but aggressive. (by Mark Galeotti MT/ 06.03.2018)

In that same article Mark Galeotti brings up the topic of different Russian groups that might be involved in the whole issue. As seen above, in addition to the familiar GRU, he provides information on FSB describing them as "operating without rules", "with impunity", powerful enough", as well as "amateurish, but aggressive" which actually fits the concerns voiced by some experts that the op was carried out sloppily. In a subsequent article the same journalist provides information on yet another agency operating in Russia, i.e. the Foreign Intelligence Service (SVR) (see MT/ 06.09.2018). This enumeration of various structures operating under the rule of the Kremlin leaves one wondering how many more structures there are doing whatever they want without being mentioned anywhere. And if one might think that it is probably a biased opinion of a journalist, there are also other articles that support the opinion voiced by Galeotti, such as:

[69] Putin's Swashbuckling Spies Are Hurting Him (Op-ed) /h/ Russian President Vladimir Putin should be as concerned as Josef Stalin was in the 1930s about the GRU's excessive appetite for risk /sh/ [...] Although no GRU officers have actually been arrested as a result of the failures, the string of mishaps resembles - at least in scale - the GRU's nightmare period from the late 1920s to the mid-1930s. During those years, European intelligence services rolled up one GRU-run spy network after another. (by Leonid Bershidsky - MT/ 06.09.2018); [70] “Дейли телеграф”: Москва тревожи Лондон с опит да изгради нова шпионска мрежа $/ \mathrm{h} /$ Според два материала на изданието Службата за външно разузнаване (СВР) на Русия опитва да запълни вакуума, оставен от военното разузнаване, известно със съкращението ГРУ, след отравянето на бившия двоен агент Сергей Скрипал в Солсбъри през март миналата година ('Daily Telegraph: Moscow worries London with an attempt to build new spy network $/ \mathrm{h} /$ According to two articles in the publication, Russia's Foreign Intelligence Service (FIS) is trying to fill the vacuum left by military intelligence, known by the acronym GRU, after the poisoning of former double agent Sergei Skripal in Salisbury in March last year.' - Dn/ 07.01.2019), see also [24].

The example unequivocally reiterates the fact that Russian spies are prone to taking risks and sometimes performing their tasks in a manner that is far from perfect. Resorting to past history Berdinsky implies the possibility of there being more than one GRU network. The implication is voiced once again in an article from the British Daily Telegraph published in the Bulgarian Dnevnik where the new service is named as the Foreign Intelligence Service which has been a 
part of the KGB and has more resources and more freedom of action than GRU. Not much else is known apart from that though, and this is disconcerting. In addition to the uncertainties surrounding the real agencies sending their officers to do different wet jobs and carry out tasks, the general public is left in a state of panic as they do not know where such individuals might show up or what they could do. As reported by the Bulgarian Dnevnik Russian spies who have been caught have been accused not only of personal attacks against ex-spies but also of messing with elections and cyber-attacks, among other activities:

[71] Освен Чепига и Мишкин други девет служители на ГУ са санкционирани заради намесата си в избори в САЩ, а четирима за кибератаки срещу Световната антидопингова агенция (WADA) и Организацията за забрана на химическите орьжия (O3XO) ('In addition to Chepiga and Mishkin, nine other GI officials have been sanctioned for meddling in US elections, and four for cyberattacks against the World Anti-Doping Agency (WADA) and the Organization for the Prohibition of Chemical Weapons (OPCW).' - Dn/ 20.12.2018).

Sometimes their activities in a place remain covered for a few years - a fact which was suggested through the link between the attempted poisoning of the Bulgarian businessman Emilian Gebrev and the Skripal's case. This information has given the reason for some journalists to speculate that because of its low profile on the international political scene as well as probably due to its past close relations with Russia, Bulgaria might have been chosen as a testing site for Russia's hybrid weapons:

[72] България - мястото, където Русия изпробва хибридните си оръжия /h/ [...] Да се върнем на Българската следа. Ако погледнем хронологията на събитията се вижда, че България е сред първите страни, станали обект на атаките. Случаят “Гебрев” сьщо предхожда “Скрипал” с три години. Дали България не е своеобразен полигон за изпробване на руските (хибридни) оръжия? Защо обаче - за разлика от западните си колеги - българските служби се притесняват в продължение на години да посочат виновниците? ('Bulgaria - the place where Russia is testing its hybrid weapons / h / [...] Let's go back to the Bulgarian trace. If we look at the chronology of events, we can see that Bulgaria was among the first countries to be attacked. The Gebrev case also precedes Skripal by three years. Isn't Bulgaria a kind of testing ground for Russian (hybrid) weapons? However, why - unlike their Western counterparts - the Bulgarian services have been worried for years to identify the culprits?' - Dn/ 14.03.2019); [73] “Новичок", VX, VG... какви са тези отрови $/ \mathrm{h} /$ Понеже създатели на съветското оръжие твърдят, че то умишлено е направено така, че да се прикрива като пестицид за индустриални цели, ви представяме описание каква е 
разликата между “новичок”, използвания неотдавна за покушение VX и защо е забранен "Амитон”. (“"Novichok", VX, VG ... what are these poisons / $\mathrm{h}$ / Because the creators of the Soviet weapon claim that it is deliberately made to disguise itself as a pesticide for industrial purposes, we present a description of what is the difference between "novichok", VX which was recently used in an assassination attempt and why Amiton was banned' - Dn/ 18.02.2019)

Although the article is meant to inform, so that people are aware of how different chemical weapons, i.e. poisons, work, the presence of such information combined with the possibility of a people used as guinea pigs is enough to stir panic and instill fear. In a succession of articles people are indirectly told that there are clandestine activities happening in their country, executed by unknown men, using lethal substances that are invisible and can easily be taken for something harmless. So rather than making them aware and providing them with information such articles instill fear.

\section{Conclusions}

The paper made an attempt at analysing media discourse on spies and most specifically the various aspects around the presentation of the poisoning of double agent Sergei Skripal in Salisbury, England. To that purpose the analysis covered articles published in the British The Independent, the Russian The Moscow Times and the Bulgarian Dnevnik so that three different perspectives on the case are presented.

Some of the main conclusions reached are as follows:

- The different newspapers frame the attack in a way corresponding to their stand in the case. Thus, the focus of The Independent is on the people affected, the place and the weapon of the attack and these elements of the spy frame have been foregrounded in the titles of its articles. The Moscow Times as a representative of the country being accused focuses mostly on its officials with Putin taking a leading role and the victim is only presented through his past relations with the Kremlin, however, being opositionally-inclined, the newspaper does comment on and analyse Skripal's significance. The Bulgarian Dnevnik focuses mostly on the Bulgarian link with the case and provides information on the alleged perpetrators expanding the network of spies involved in the case, giving information on the poison, however, refraining from blaming any victims or taking a firm stance on the matter.

- The tone of the newspapers is also different as the UK is trying to present itself in a positive light as the protector of Skripal and as a country that operates following civilized rules and the European laws. Russia is 
presented as aggressive, defensive, and arrogant, which is actually the old dichotomy good vs. bad reflected in the West - East division in which everything that comes from the East is considered bad, uncivilized and scary, while the aspects associated with the West are just the opposite.

- The analysed articles thematically fall within four main groups presented in this paper as: The Life of a Spy, The Blame Game, Flexing Muscles, and Expansion and Scare. Each one of these groups presents a different aspect of the case, however, they frequently merge into one another and jointly instill fear and uncertainty in the general public. Thus for example, The Life of a Spy group mostly provides information on the specificities of the spying job with the possible errands that can be given, people involved, the actual method of operation, results and weapons. The Blame Game focuses on the language used to present one of the sides as the culprit, however, this usually involves the mentioning of more spies, secret services organizations, laboratories and the heads of the UK and Russia accusing each other of unfair politics and staging the whole case. The articles in this group very frequently resort to outlining the capability, intent and motive necessary for such an operation to be carried out which are also frequently used in the Flexing Muscles group and generally stir panic. The metaphoric expression is mostly related to the way the two countries try to show their power and influence and the ways they do that. As the analysis has indicated, both countries boast about the skill of their agents with Russia focusing on their impeccability and expertise which is generally linked to an array of dead targets, poisons, and other covert operations carried in various places all over the world. The last naturally leads to the idea of expansion of the case as it is never only a matter of single kill but a sequence of events and activities involving many people (not only the target and the perpetrators, but possibly some collateral victims or additional targets, such as family members, etc.) which logically leads to the piling up of fear in the general public of an enemy that is difficult to see and means difficult to tell.

- The language used, especially in the Blame Game and Flexing Muscles is reflective of the self-esteem both the UK and Russia have as world powers and former empires. Putin allows himself to use derogatory language when he refers to Skripal and to confront the UK in their accusations. The UK retort with strong words describing the activities of Russia.

Having said all that, it can be concluded that the paper makes a contribution to the media discourse on spies and the activities of secret services. Still, as its focus is only on one particular case presented in three newspapers, more conclusions might be reached should a more comprehensive analysis be carried 
on several of the cases involving secret agents covered in a bigger number of newspapers.

\section{References:}

Arcimaviciene, L. (2013). The US-Russia spy swap of 2010 in media discourse: What the commersial transaction metaphor implies. Discourse, Context \& Media, 2, 1421, Elsevier.

Carter, M. J. (2017). The hermeneutics of frames and framing: An examination of the media's construction of reality. SAGE Open, April-June, 1-12.

Cheshmedzhieva-Stoycheva, D. (2017). Getting to know the Other: Igor Karkaroff - A key Bulgarian figure in J. K. Rowling's "Harry Potter and the goblet of fire". In V. Kambovski et al. (eds.), KNOWLEDGE - International Journal, 19(3 September), 1077-1081. GRAFOPROM - Bitola.

Dubov, M. (2017, June 11). Rahab ("the Harlot") and the Spies - For an informed reading of Joshua 2:1-24. Retrieved February 11, 2020, from https://www.chabad. org/library/article_cdo/aid/3700192/jewish/Rahab-the-Harlot-and-the-Spies.htm

Ehoward. (2016, August 9). Espionage in Ancient Rome. Retrieved February 11, 2020, from https://www.historynet.com/espionage-in-ancient-rome.htm

Espionage. (2020, January 31). Retrieved February 11, 2020, from https://en.wikipedia. org/wiki/Espionage

Fillmore Ch., \& Baker, C. (2009). A frames approach to semantic analysis. Ch. 13. In B. Heine \& H. Narrog (eds.), The Oxford handbook of linguistic analysis (pp. 313339). OUP.

GRU. (n.d.) Collins English Dictionary - Complete and Unabridged, 12th Edition 2014. (1991, 1994, 1998, 2000, 2003, 2006, 2007, 2009, 2011, 2014). Retrieved February 12, 2020 from https://www.thefreedictionary.com/GRU

Ivanov, I., \& Cheshmedzhieva-Stoycheva, D. (2012). "Russians in the Bulgarian and the British press". Savremenni aspekti v anglitsistikata v sapostavitelen plan, 54-62. Shumen: Konstantin Preslavsky University.

Ivanova, I. (2020). Pragmatic functions of interrogatives in media texts. Media Linguistics Journal, 7(4). Upcoming.

KGB. (n.d.) Collins English Dictionary - Complete and Unabridged, 12th Edition 2014. (1991, 1994, 1998, 2000, 2003, 2006, 2007, 2009, 2011, 2014). Retrieved February 12, 2020 from https://www.thefreedictionary.com/KGB

Kostova, L. (1997). Tales of the periphery. Veliko Turnovo: Cyril and Methodius UP.

Lovelace, A. G. (2015). Spies in the news: Soviet espionage in the American media during World War II and the beginning of the Cold War. Journal of Slavic Military Studies, 28, 307-327. Routledge: Taylor and Frances Group.

Macintyre, B. (2019). The spy and the traitor: The greatest espionage story of the Cold War. UK: Viking. 
Mercouris, A. (2016). Western racism and the stereotyping of Russians. The Duran. 12 October 2016, http://theduran.com/western-racism-and-the-stereotyping-ofrussians/

Milton, G. (2014, May 4). These Are the Guys Who Invented Modern Espionage. Retrieved February 11, 2020, from http://historynewsnetwork.org/ article/155464\#sthash.7MXUDisL.dpuf

United States Holocaust Memorial Museum. "Introduction to the Holocaust." Holocaust Encyclopedia. https://encyclopedia.ushmm.org/content/en/article/introduction-tothe-holocaust. Retrieved March 1, 2020.

Urban, M. (2018). The Skripal files: The life and near death of a Russian spy. Henry Holt and Co.

Yuen, D. M. C. (2014). Deciphering Sun Tzu: how to read The art of war. New York: Oxford University Press. 